\title{
Profitabilities and Constraints to Sweet Potato Production in Nigeria
}

\author{
Udemezue JC* \\ National Root Crops Research Institute, Nigeria
}

Submission: April 25, 2019; Published: May 15, 2019

*Corresponding author: Udemezue JC, National Root Crops Research Institute, Umudike, PMB7006 Umudike Abia State, Nigeria

\begin{abstract}
Nigeria is one of the largest producers of sweet potato in sub-Saharan Africa with annual production estimated at 3.46 million tons per year. It is an important food security and early maturity crop that can be intercropped with some crops like yam and maize. Sweet potato can also be a mono crop based on the intentions of the farmer. In Nigeria, more than $85 \%$ of the sweet potato production is done by farmers who maintain small scale farming and carry out their operations manually with traditional farm tools. Despite the economic importance the crop, Nigeria is still at declining stage in spite of the various incentives by the government to boost massive production. Farmers' output still falls below 60 percent and to arrest the condition, this paper recommended that; The means of production technology should be improved as well as other factors that support farmers output should be given adequate attention. The use of modern agricultural equipment to enhance mass production of sweet potato which could lead to export of sweet potatoes to other country should be encouraged.
\end{abstract}

There is need to encourage more research work on the poor variety of seeds that is currently used by the farmers. The existing research centre established by the government for potato research such as National Root Crops Research Institute, Umudike and potato research institute Jos should be strengthened to achieve their mandate. Farmers and processors of sweet potatoes need to be assisted with improved technologies and increased financial assistance to be able to acquire modern equipment for production, processing and marketing of potatoes.

Keywords: Sweet potato; Potentials; Constraints

\section{Introduction}

Sweet potato is a major crop that suffered serious neglect in the past but now occupies a global position as a source of food and industrial raw material [1]. Nigeria is the number one producer of sweet potato in Africa with annual output of 3.46 million metric tons and globally the second largest producer after China. However, it is the only crop among the root and tuber crops that has a positive per capita annual rate of increase in production in sub-Saharan Africa [2]. Crop productivity in Nigeria is still at declining stage in spite of the various incentives by the government to boost massive production. Farmers' output still falls below 60 percent and to arrest the condition, the means of production (technology) should be improved as well as other factors that support farmers output should be given adequate attention. The poor output by the farmers may be an indication that the resources needed for production are not being utilized at the optimal levels. There is a need to document sweet potato production, particularly at a time when a variety of approaches to poverty alleviation are being considered by the Nigerian government and their development partners. The crop is cheap, inexpensive and is easily cultivated, yet it is facing a 1ot of production and post-harvest challenges. Industrial potentials of sweet potato have not been exploited due to a chronic lack of awareness of the commercial benefits derived from sweet potato.

Sweet potato (Ipomoea batatas(L)) is a herbaceous, warm-weather creeping plant that belongs to the family of Convolvulaceae and genus of Ipomoea [3]. The family is made up of 45 genera and 1,000 species. It grows best at a temperature of between $240 \mathrm{C}$ and $280 \mathrm{C}$ with annual rainfall of $1000 \mathrm{~mm}$ to $7000 \mathrm{~mm}$.

Ezeano noted that Ipomoea batatas originated from Central America and Northwestern part of South America in about 300 B.C and later introduced into Europe in the $16^{\text {th }}$ century. Presently, it is grown throughout the world from latitude $40^{\circ \mathrm{N}}$ to latitude $35^{\circ \mathrm{s}}$. It was first introduced into Nigeria in the late 16941698 through the early activities of Portuguese and Spanish explorers [3]. Production of sweet potato was encouraged by the British colonial government during the Second World War as their tubers were needed to feed their armed forces in West Africa. Since then, the impotence of potato has been widely realized such that it is now an important commodity in both local and international trade [2]. 
Nigeria is one of the largest producers of sweet potato in sub-Saharan Africa with annual production estimated at 3.46 million tons per year. Sweet potato is an important food security and early maturity crop that can be intercropped with some crops like yam and maize. It can also be a mono crop based on the intentions of the farmer. A brief analysis of potato production in various countries of Africa reveals that Egypt is African's number one potato producers, followed by Malawi while Nigeria is known as the fourth biggest producer in Africa [4].

In Nigeria, more than $85 \%$ of the sweet potato production is done by farmers who maintain small farms and carry out their operations manually with traditional farm tools such as hoes and machetes [5]. According to Ugonna, et al. [4], the main sweet potato growing area in Nigeria is Jos Plateau and this could be attributed to its altitudes which range from 1200 to $1400 \mathrm{~m}$ and summer temperature that rarely exceed $35 \mathrm{c}$ which make the temperate climate suitable for potato production.

Sweet potato has been identified to be the fourth most important root crop in Nigeria after cassava, yam and cocoyam [5]. Sweet potato offers a particularly significant potential for increasing food production and income in Nigeria. Like other agricultural crops, it has a role to play in the developing economies by providing job opportunities to farmer through the increment of their income. Sweet potato is consumed without much processing in most parts of the tropics. It is either eaten boiled, roasted or fried. In countries like the United States, it is dehydrated into chips, canned, cooked and frozen, creamed and used as pie fillings. It could also be dried and ground into flour to make biscuits, bread and other pastries. Sweet potato can be pounded together with yam to give a delicious meal. Despite the fact that sweet potato is a crop that is being consumed in all parts of the country, yet its level of production still remains low [6]. Sweet potato has a particularly significant potential for increasing total food production and income in Nigeria. Industrially, sweet potato flour can be used to replace wheat flour in bread making or maize flour in balanced feeds. Baby foods have also been formulated using sweet potato.

Despite the growing importance of sweet potato in respect to economic development, there are still impediments working against sweet potato production in Nigeria. In line with the above, this paper used available literatures to review the profitabilities and constraints to sweet potato production in Nigeria.

\section{Profitability of sweet potato production}

Sweet potato is a staple food in many tropical countries. It is one of the world's highest yielding crops with the total food production per unit area exceeding that of rice by having greater food value. It is an important food crop in tropical land and subtropical countries and grown in a large scale in Mexico, central America, South America, Mediterranean regions of Europe, Africa, India, China, Japan, South East Asia, East Indies and pacific Island [7].
Sweet potato offers a particular significant potential for increasing food production and income in Nigeria like other agricultural crops. It provides job-opportunities for farmers as well as raising their income. Both the leaves and roots of sweet potato are used as animal feed. Industrially, sweet potato flour can be used to substitute wheat flour in bread making or maize flour in balanced diet. It is also used in the brewing of alcoholic drinks and non-alcoholic drinks in the brewing industries and its starch can also be used in textile, glue, paint and cardboard industries $[8,6]$.

It is a major source of carbohydrate for millions of people, especially in developing countries. Its tuberous roots contain about $27 \%$ carbohydrate and high concentrations of vitamin A, C, calcium and iron. Fresh sweet potato provides about $50 \%$ more calories than Irish potatoes. Sweet potato is a great source of minerals like manganese, Folate, copper and iron. The darkercolored variety is a great source of Carotenes (Precursor of vitamin A), Vitamin C, B2, B6 E and biotin. It is also a fantastic source of dietary fibre [9].

With regard to the above, research has shown nine reasons why sweet potato should be eaten and they as follows: $[10,11]$.

i. Sweet potato is high in antioxidants which work in the body to prevent inflammatory problems such as asthma, arthritis, gout among others.

ii. Sweet potato is an excellent source of carbohydrates for those with blood sugar problems, these fibrous root vegetables can help regulate blood sugar level and prevent conditions like insulin resistance.

iii. Sweet potato is healthy for the digestive tract. Being rich in digestive fibre, especially when the skin is also consumed, it helps to reduce constipation and may prevent colon cancer.

iv. It is good for those who are pregnant or trying to conceive because they are high in folate which is essential for the healthy development of fatal cell and tissue.

v. Parked with important vitamins and other nutrients, eating sweet potatoes can boost immunity by supporting the needs of the body.

vi. It is good for preventing heart disease. High in potassium, also help to maintain fluid and electrolyte balance in the body, which is important for stabilizing blood pressure and regulating heart function.

vii. Sweet potato is good for alleviating muscle cramps. Potassium deficiencies are a leading cause of muscle cramps as well as injuries by making sweet potatoes a regular part of your diet (along with proper exercise), you can expect an energy boost and fewer muscle cramps and injuries.

viii. It is good for treating stress-related symptoms. The body tends to use a lot of potassium and other important 
minerals when it is under stress. Sweet potatoes provide important minerals that help to maintain balance throughout the body during times of stress.

ix. Finally, sweet potato ranked number one in nutrition out of all vegetables by the centre for science in the public interest because they are such a rich source of dietary fibre, natural sugars, complex carbohydrates, protein, carotenoids, vitamin $\mathrm{C}$, iron and calcium.

All in all, with the growing food crisis and high prices of the main stream food crops like rice, maize, beans among others, there should also be a growing recognition of the importance of local crops such as sweet potato in supporting livelihoods for the poor. This crop has the potentials to diversify the farming system, spread risks, contribute to food security and also provide income opportunities for the most vulnerable farmers in the country. Therefore, if sweet potato commercialization efforts are to be put in place, then a majority of the farmer would be better off.

\section{Constraints to sweet potato production in nigeria}

Sweet potato yields in Nigeria are generally below the world's average, and not encouraging when compared to other countries. For instance, African countries such as Rwanda, Kenya, Ethiopia and Tunisha have average yields of up to 30 tons per hectare [11]. This is a far cry from yields in Nigerian farmers' fields which are as low as 8 tons per hectare. The major culprit for this low output may be inadequate supply of good quality seed potato to farmers. Therefore, it behooves this study to evaluate the challenges facing sweet potato production and processing in Nigeria. Ugonna et al. [4] have identified a number of factors that limit sweet potato production and these are;

Inadequate supply of good quality seeds: The quality of seeds available in the country affects the yield of potato tuber produced. The improved variety of seeds which was imported into the country has been used for a number of times as such the potency is reduced.

Inadequate storage facilities: The storage facilities available to farmers are the traditional methods which do not store the potato tuber to last for more than one month. This increases the loss of potato tuber and seed, therefore makes farmers to sell off their produce as soon as it is harvested.

Poor disease and pest management: The management of disease and pest that affect sweet potato is one of the major problems that farmers face as it reduces their potato yield and may even destroy the crop once the farm is affected.

High cost of production: The high cost of good seeds, labour and farming equipment are the major constraint to the quality of potato produced. However, many farmers cannot afford to buy the equipment which will increase their yield output.
Climatic limitations: Potato has been found to grow only in temperate areas, restricting the areas where potato can be grown to increase the yield.

Activities of middle-men: The high handling charges by the middlemen affects the price of the potato and also control the market.

Marketing problems: The poor transportation facilities from rural to the urban areas and the use of traditional baskets sack and trays for transportation damage the goods.

Inadequate funding of research work: lack of funds in carrying out research work on potatoes inhabits the findings of solutions to the problems faced by farmers.

Lack of agricultural equipment: Inadequate agricultural equipment affects the production output, thus leads to reduce quality produced by farmers. In the light of the above, Ugonna et al. [4] suggested that the following strategies should be used to improve the above challenges. The use of modern agricultural equipment to enhance mass production of potato which could lead to export of potatoes to other country should be encouraged.

There is need to encourage more research work on the poor variety of seeds that is currently used by farmers. The existing research centre established by the government for potato research such as National Root Crops Research Institute, Umudike and potato research institute Jos should be strengthened to achieve their mandate.

Farmers and processors of potatoes need to be assisted with improved technologies and increased financial assistance to be able to acquire modern equipment for production, processing and marketing of potatoes.

There is need to encourage collaboration of relevant organizations to reverse the areas of weakness and boost awareness creation of the importance of potatoes as important energy source and above all "a hidden treasure" in the world food need. On the other hand, in a study conducted by Omoare, et al. it was observed that the major constraint confronting the farmers with regard to potato production and processing were inadequate finance for sweet potato production and processing low farmers' knowledge on sweet potato value addition, high cost of sweet potato processing equipment, bulkiness and perishability of sweet potato, too much attention on other roots and tuber crops and inadequate extension service.

A study conducted by Olagunji, et al. [2] on the gender analysis of sweet potato production in Osun state, Nigeria, observed age, educational status, marital status, extension visits and household size as an impediment to sweet potato production. However, on their opinion age related negatively with the efficiency of productivity and it is significant at $1 \%$ productivity level. This implies that ageing is in consonance with inefficiency of productivity. More so, educational status, marital 
status, number of extension visits and household size were related positively with efficiency of productivity. Therefore, increase in these factors could result to increase efficiency in productivity of the sweet potato production.

In the same vein, Fawole [12] opinioned that the constraints militating against sweet potato production in Kwara state, Nigeria as inadequate government aid to farmers, high labour cost, no access to credit, poor storage facilities of the farmers, poor marketing outlet, high incidence of pest and diseases and low access to improved sweet potato varieties. A study carried out by Benjamin, et al. on the determinant of the farmer's preference of sweet potato varieties, production constraints and farmers' coping strategies in Kenya shown that pest, disease and drought were the major constraints militating against sweet potato production in Kenya.

Mbanaso [3], asserted the major constraints to adoption of sweet potato as production/processing complexity problems, economic problems, poor technical information and pathological problems. He further indicated that adoption of sweet potato technologies was significantly influenced by household size, labour, land, health, age, marital status and access to credit therein. However, Schltz 1995 in Udemezue [13] indicated that the probability of adopting a new technology will depend on the difference in profitability between the new and old technologies and the ability of the farmers to perceive the advantage and efficiently utilize the new technology. In the light of the above, the constraint to sweet potato production in Nigeria are as follows; Disease/pest infestation, high perishability of the product, farmers' low knowledge on sweet potato production technologies, bad road network, lack of governmental aids to farmers, high cost of sweet potato processing equipment, inadequate storage facility and too much attention on other crops

\section{Conclusion and Recommendations}

Sweet potato has been identified to be the fourth most important root crop in Nigeria after cassava, yam and cocoyam. Sweet potato offers a particularly significant potential for increasing food production and income in Nigeria. Like other agricultural crops, it has a role to play in the developing economies by providing job opportunities to farmer through the increment of their income. Sweet potato is consumed without much processing in most parts of the tropics. Sweet potato yields in Nigeria are generally below the world's average, and not encouraging when compared to other countries. For instance, African countries such as Rwanda, Kenya, Ethiopia and Tunisha have average yields of up to 30 tons per hectare. This is a far cry from yields in Nigerian farmers' fields which are as low as 8 tons per hectare. The major cause of this low output may be inadequate supply of good quality seed potato to farmers, production/processing complexity problems, economic problems, poor technical information, and pathological problems, among others. With respect to the findings above, it is recommended that frequency of extension contact with farmer and the nature of the technology under dissemination could reduce the constraints militating against the technology. Frequent content with extension agent and the attribute of the innovation in terms of productivity significantly contributed to the adoption of improved varieties among farmers.

Also, with the growing food crisis and high prices of the main stream food crops like rice, maize, beans among others, there should also be a growing recognition of the importance of treasure crops such as sweet potato in supporting livelihoods for the poor. This crop has the potentials to diversify the farming system, spread risks, contribute to food security and also provide income opportunities for the most vulnerable farmers in the country. Therefore, if sweet potato commercialization efforts are to be put in place, then a majority of the farmer would be better off. More so, the use of modern agricultural equipment to enhance mass production of potato which could lead to export of potatoes to other country should be encouraged. There is need to encourage more research work on the poor variety of seeds that is currently used by farmers. The existing research centre established by the government for potato research such as National Root Crops Research Institute, Umudike and potato research institute Jos should be strengthened to achieve their mandate. Farmers and processors of potatoes need to be assisted with improved technologies and increased financial assistance to be able to acquire modern equipment for production, processing and marketing of potatoes.

\section{References}

1. Njoku JC (2007) Effect of cultiva and time of harvested on yield and Total Carotenoid Content of Carotene-Based Sweet Potato cultivas NRCRI. Annual report. Pp 45-53.

2. Olagunju FI, Fakayode S B, Babatunde RO, Ogunwole-Olapade F (2013) Gender analysis of sweet potato production in Osun State, Nigeria. AJAEES 2(1): 1-13.

3. Mbanaso EO (2010) Adoption and dis-adoption of sweetpotato Production and processing technologies by farmers in South-Eastern Nigeria. Ph.D thesis, department of agricultural extension, University of Nigeria, Nsukka. Pp. 1-104.

4. Ugonna CU, Jolaoso MO, Onwualu AP (2013) A Technological Appraisal of Potato Value Chain in Nigeria. International Research Journal of Agriculture, Science and Soil Science 3(8): 767-769.

5. Okonkwo JC, Amadi CO, Nwosu KI (2009) Potato production, storage, processing and utilization in Nigeria. National Root Crops Research Institute, Umudike, Nigeria. Pp 67-69.

6. Mathew 0, Fatimoh A (2008) Profitability and Technical Efficiency of Sweet potato Production in Nigeria. Journal of Rural Development 31(5): 105-120.

7. Sushanta KJ, Nedunchezhian M, Misra RS (2011) The triple "F" (Food, Fodder and Fuel) crop sweet potato (Ipomoea batatas(L)Lam) Orissa Review, 1: 82-92.

8. Agbo I, Ene CSO (1992) Status of Sweet potato production and research in Nigeria. Sweet potato situation and Priority in Research in West Africa. Proceedings of a workshop held in Dovla, Cameroon from July $27^{\text {th }}$ to $29^{\text {th }}$. International Sweet potato Research Center, Lima, Peru. 
9. Coleman SW, Moore JE (2003) Feed quality and animal performance. Field Crop Research 84: 17-29.

10. http://www.naturalnews.com/831543-sweet-potato-minerals.html

11. Dabels VY, Kwis D (2013) Yield trail of some hybrid clones with local checks. National Root Crops Research Institute, Umudike. Annual Report pp 68.
12. Fawole OP (2007) Sustainable food crop production through multiple cropping patterns among farmers in South West Nigeria. Journal of Human Ecology 21(4): 245-249.

13. Udemezue JC (2014) Adoption of FARO-44 Rice production and processing Technologies by farmers in Anambra state, Nigeria. M.Sc Thesis, department of agricultural extension, University of Nigeria, Nsukka, Pp 24.

\section{Your next submission with Juniper Publishers} will reach you the below assets

- Quality Editorial service

- Swift Peer Review

- Reprints availability

- E-prints Service

- Manuscript Podcast for convenient understanding

- Global attainment for your research

- Manuscript accessibility in different formats

( Pdf, E-pub, Full Text, Audio)

- Unceasing customer service

Track the below URL for one-step submission https://juniperpublishers.com/online-submission.php 